Author contacts: $\underline{\text { k.douglas@ @ent.ac.uk and r.sutton@kent.ac.uk }}$

\title{
Climate change: Why the conspiracy theories are dangerous
}

\section{Karen M. Douglas and Robbie M. Sutton}

\begin{abstract}
Uncertainty surrounds the public understanding of climate change, and provides fertile ground for conspiracy theories. Typically, such conspiracy theories assert that climate scientists and politicians are distorting or hijacking the science to suit their own purposes. Climate change conspiracy theories resemble other conspiracy theories in some respects, but in other respects they appear to be quite different. For example, climate change conspiracy theories appear to be motivated by the desire to deny or minimize an unwelcome and threatening conclusion. They also appear to be more contentious than other types of conspiracy theories. Perhaps to an unparalleled extent, people on both sides of the issue champion climate change conspiracy theories. Finally, more than other conspiracy theories, those concerning climate change appear to be more politically loaded, dividing opinion across the left-right continuum. Some empirical evidence suggests that climate change conspiracy theories may be harmful, steering people away from environmentally friendly initiatives. They therefore present a significant challenge for governments and environmental organizations that are attempting to convince people to take action against global warming.
\end{abstract}




\section{Keywords}

climate change, conspiracy theories, motivated reasoning, scientific consensus

In 2006 hurricane expert Bill Gray, an emeritus professor of atmospheric science at Colorado State University, called global warming "one of the greatest hoaxes ever perpetrated on the American people" (Achenbach, 2006) and said that after a period of warming, the Earth would begin to cool again in three to eight years. Eight years on, the Earth is still warming (NASA, 2014) but, if anything, the voices alleging conspiracy have become louder.

When prominent experts such as Gray speak, people listen. As an expert on meteorology, he is a trusted source of information about the world's climate. Other well-known climate skeptics include US Senator James Inhofe, who wrote The Greatest Hoax: How the Global Warming Conspiracy Threatens Your Future (2012) and again chairs the Senate's Environment and Public Works Committee; former Northern Irish environmental minister Sammy Wilson; former US vice presidential candidate Sarah Palin; and former president of the Czech Republic Václav Klaus (Monbiot, 2009).

When people are unsure of the facts and lack the necessary knowledge and skills to interpret data themselves, they understandably turn to trusted experts to guide their opinions and behaviors. However, when people listen to climate skeptics, they enter a 
minefield of mistrust, suspicion, and doubt. By no means do all skeptics advance conspiracy theories to discredit mainstream science and environmental policy. Nonetheless, theories abound that assert climate scientists are faking their data to obtain more research funding. Or, global warming is an attempt to promote nuclear power. Or, it is a scam cooked up by people who own shares in renewable energy companies. Or, it is a myth spread by environmentalists in the pursuit of a one-world socialist government. These are all conspiracy theories that have the power to influence what people think and do.

Climate change conspiracy theories resemble other conspiracy theories in some respects, but in other respects they may be uniquely harmful, steering public opinion and policy away from efforts to reduce, and adapt to, the impacts of global warming. Although conspiracy theories are more common, and more studied, than ever before, psychologists have paid relatively little attention to the unique properties of climate change conspiracy theories. This article attempts to identify what such theories have in common with, and what might set them apart from, other conspiracy theories.

\section{Out of the ordinary}

Generally, when something big happens, such as the death of a president or a terrorist attack on a major city, people want answers. But for many people the answers given by officialdom are not enough. Instead they turn to allegations of collusion, intrigue, and cover-ups. Popularly known as conspiracy theories, these allege that such events are the 
secret actions of powerful and malevolent groups_-rather than accidents, natural occurrences, or the overt actions of officially identified perpetrators (McCauley and Jacques, 1979). Conspiracy theories are a prevalent feature of contemporary culture, assisted by the ease and speed of digital communication (Coady, 2006). They capture public awareness, drawing attention away from conclusions supported by scientific evidence and logic and toward explanations that involve complex schemes and plots.

Conspiracy theories range from outlandish (for example, that Barack Obama and other world leaders are reptiles in human guise) to unproven (that the US government was at least complicit, and at worst responsible, for the $9 / 11$ attacks) to true (the Watergate affair and the Tuskegee syphilis scandal). Other well-known conspiracy theories include the notion that Lee Harvey Oswald worked with the CIA to assassinate President John F. Kennedy; that elements within the British establishment killed Diana, Princess of Wales; and that NASA faked the Apollo moon landings. In general, people find it difficult to believe that such significant events can be explained by mundane or ordinary details (Leman and Cinnirella, 2007).

Climate change is perhaps a supreme example of this "proportionality bias." It is a global-scale event with enormous significance, and is portrayed by scientists and governments as a consequence of small, everyday factors such as the transport we use. It is perhaps no surprise, then, that there are many conspiracy theories about climate change. Such theories typically postulate that global warming is not happening and 
instead that scientific findings are being exaggerated or fabricated by people who have something to gain. Because they all have this thread in common, they are often referred to collectively as the Great Global Warming Conspiracy. However, the motives and perpetrators identified by the various theories are not always the same. Among the most popular theories:

Scientists are making it up for political reasons. According to this theory, scientists are fabricating or tweaking their data to gain political power and to support politicians' strivings for power. For example, Bill Gray has argued that global warming gives scientists and politicians a cause that will allow them to "organize, propagandize, force conformity and exercise political influence" (Achenbach, 2006). In short, this theory argues that the case for global warming is a political stunt.

Scientists are making it up to get research funding. An alternative theory, but one that still blames the scientists, is that data are fabricated or distorted because climate scientists generally struggle to secure research funding. Alarming data increase the likelihood that future research will be supported, so climate scientists are motivated to lie about their data to increase their chances of success. This theory implies that a cohesive cabal of climate scientists have managed to con governments worldwide and even dupe the United Nations into endorsing their lies. 
Global warming is a green scam. Another conspiracy theory argues that because many people have invested in renewable energy companies, they stand to lose a lot of money if global warming is shown to be a myth. According to this theory, environmental groups therefore bribe climate scientists to doctor their data so that they are able to secure their financial investment in green energy.

Global warming is an attempt to promote nuclear power. Although its life cycle is not entirely carbon-free, nuclear power production emits relatively small amounts of the greenhouse gas carbon dioxide, and therefore does not contribute significantly to global warming. One of the many claims made in the 2007 British documentary "The Great Global Warming Swindle" is that the threat of global warming is an attempt to promote nuclear power. Ultimately, companies in the nuclear sector stand to profit if nations become more dependent on nuclear power. Indeed, any scheme that puts a price on carbon emissions is likely to benefit nuclear power.

\section{Similarities and differences}

In the examples above, the alleged conspirators are driven by either political power or money. This is much the same for many other conspiracy theories. For example, some argue that the 9/11 attacks were all about oil, that Princess Diana was murdered because she posed a threat to British political stability, and that President Kennedy was assassinated because he was unpopular with powerful people and groups such as the CIA and the Mafia. Someone always had something to gain-financial or political (or 
both) - from these events. Similarly, all climate change conspiracy theories surmise that global warming is a scam manufactured by those who have something to gain from it (although the perpetrators vary from theory to theory).

But this may be where the similarities between climate change conspiracy theories and other popular conspiracy theories end. So far, social scientists have not conducted systematic research to examine exactly how belief in conspiracy theories about climate change is similar to, or different from, other conspiracy beliefs. While researchers await a new wave of studies focused on climate change conspiracy beliefs, comparing climate change conspiracy theories with other popular conspiracy theories reveals some crucial differences.

\section{Motivated reasoning}

One key difference is that people have multiple, deep-seated reasons to believe in climate change conspiracy theories. Most people prefer to believe that they are part of an enduring and moral social group that can be confident and strong in the face of conflict and threat (Tajfel and Turner, 1979; Wohl et al., 2010). They also prefer to perceive themselves as moral individuals. Indeed, self-enhancement - the motivation to feel good about oneself and maintain self-esteem-is seen as universal (Sedikides et al., 2003). Although sometimes unrealistic, people are also motivated to believe that they are headed toward a bright future and that they should be optimistic about their prospects (Weinstein, 1980). It is obviously more pleasant to hold these beliefs than not 
to hold them. More than that, these beliefs appear to be fundamental to people's ability to function effectively (Taylor \& Brown, 1988).

Climate change presents a powerful threat to these fundamental and cherished beliefs about the morality of individuals (Bandura, 2007) and the legitimacy of societies (Feygina et al., 2010). The key psychological appeal of climate change conspiracy theories, then, may be that they discredit the apparently overwhelming evidence that humans are contributing to the destruction of their own environment. Denial of climate change is likely to do a lot more for people's general sense of equanimity than, say, believing that Princess Diana was murdered. Climate change conspiracy theories may therefore be a politically significant type of "motivated reasoning" (Kunda, 1990)—in which information that challenges valued beliefs is discounted, while information that supports them is accepted uncritically. Of course, it is possible for people to doubt the evidence for anthropogenic climate change without subscribing to conspiracy theories (for example, a person may believe that the planet is warming due to natural cycles), but the two are clearly correlated (Lewandowsky et al., 2013; Lieserowitz, 2006).

A related feature of climate change conspiracy theories is that they appear to be politically loaded, dividing opinion according to people's position on the spectrum between right and left. With the right wing emphasizing the production of wealth rather than its redistribution, and opposing governmental regulation and interference, it is not surprising that right-wing political identification is associated with disbelief in climate 
change. This type of disbelief is unlike the rejection of mainstream science surrounding other controversial topics such as vaccination and genetically modified foods. However, as cognitive psychologist Stephan Lewandowsky and his colleagues have shown (2013), people who have a conspiracist view of the world and who subscribe to a range of conspiracy theories are more likely to reject the mainstream scientific consensus on all three topics.

Motivated reasoning may help explain why the mounting scientific evidence of climate change only seems to have yielded more and more conspiracy theorizing and controversy. Researchers have shown that exposure to scientific evidence about climate change can polarize opinion, rather than informing it in the rational way that one might expect (Kahan et al., 2012). When climate scientists are seen as part of a left-wing elite arguing for social change, their findings may be sharply rejected. It may seem perfectly reasonable for climate scientists to point to the impact of climate change on the world's least powerful people, for example. However, such arguments appeal more to liberals than conservatives (Markowitz and Shariff, 2012). Couching arguments in terms of conservative moral values, such as a concern for purity (for example, of the environment), could potentially help defuse the perception that liberal scientists are distorting or falsifying their results for political purposes.

\section{Double-edged conspiracy}


Another important and possibly unique feature of conspiracy theories about climate change is that there are powerful theories on both sides of the debate. With regard to topics such as 9/11, President Kennedy, and the Apollo moon landings, there is a single mainstream explanation opposed by one or more conspiracy theories. In the case of climate change, however, conspiracy theories that dispute the official account (that humans are inducing dangerous levels of climate change) are countered by others that affirm it. Indeed, some of these counter-conspiracy theories suggest that the official account has not been put firmly enough. A core proposition of many, including arguments put forward by organizations such as Greenpeace (Gibson, 2012), is that industrialists are orchestrating and funding a campaign to sow seeds of doubt and denial in public opinion (Fischer, 2013).

Other conspiracy theories refer less to byzantine scheming than to backroom political machinations. For example, National Geographic reported (Howard, 2014) that important information about greenhouse gas emissions in China was removed from the summary for policy makers prepared from the fifth Intergovernmental Panel on Climate Change assessment. The apparently intentional suppression of information that may be politically inconvenient raises concern about the international politicization of climate change-specifically, that evidence of its seriousness and of its links to human behavior tends to be understated. 
Counter-conspiracy theories may gain less airtime than those that underpin the denial of climate change. Nonetheless, they draw empirical support from extensive analyses of documented links between industrial interests, think tanks, and prominent climate skeptics (Dunlap and Jacques, 2013; Oreskes and Conway, 2010)—and indeed from recent evidence that these links are becoming more byzantine and untraceable (Brulle, 2013). In short, they may be largely warranted, even unavoidable, responses to the tactics of an opposing lobby aiming to discredit mainstream science and policy.

No matter how plausible or warranted, the very existence of counter-conspiracies illustrates the corrosive and potentially recursive nature of conspiracy theorizing. In the climate change debate, conspiracy theories (for example, that scientists and governments are overstating risks for nefarious reasons) are themselves the subject of conspiracy theories (that industrialists are funding their dissemination). Both sides of the debate are therefore represented as insincere, and scientific data are represented as political tools rather than value-free observations of the world. This creates a climate of uncertainty and mutual distrust, which, especially when politicized, greatly undermines the possibility of rational debate and discourse about the appropriate policy response to scientific findings (Cohen, 2003). Perhaps most corrosive, the sum total of these effects is to create the impression that the climate change debate boils down to a choice between competing conspiracy theories. 
In a world where people disbelieve science or are unsure about the meaning of scientific claims, the sources of conspiracy theories are extremely important. When people are unsure or lack confidence in data, they tend to rely on secondhand knowledge, typically presented by authoritative media sources. But when well-known and seemingly authoritative sources endorse conspiracy theories, as in the case of Bill Gray and others mentioned earlier, people are likely to take notice (Chaiken and Maheswaran, 1994). Known as "knowledge by authority" in philosopher Charles Sanders Peirce's taxonomy of epistemology, reliance on others for information cannot guarantee impartiality or accuracy (Hovland and Weiss, 1951). Further, if climate change conspiracy theories make people doubtful of scientific claims, people may be less likely to support action or take measures to reduce the problem.

\section{Impacts of climate change conspiracy theories}

Although often parodied as inconsequential fantasies entertained by disenfranchised people on the fringes of society, conspiracy theories can influence what ordinary people intend to do in important domains. For example, social psychologist Daniel Jolley and one of the authors of this article asked people participating in a study to read a fictitious article about vaccines (Jolley and Douglas, 2014a). One set of participants read an article arguing that people within the vaccine industry are guilty of misrepresenting or hiding data about the efficacy and safety of vaccines, and that their actions are motivated by profit. These are typical conspiracy theories advocated by members of the anti-vaccine movement. The other study participants read a piece that refuted common 
anti-vaccine conspiracy theories. The study reported that people in the first group, who were exposed to the anti-vaccine conspiracy theories, were more reluctant to have a fictional child vaccinated.

Using a similar experimental design, other research has shown that people who read materials arguing that governments are involved in elaborate plots and schemes, such as the alleged 9/11 conspiracy, indicated a reluctance to vote in general elections compared to those who read information that refutes such conspiracy theories (Jolley and Douglas, 2014b). Further, research has shown that people can be influenced by exposure to conspiracy theories without being aware that they have been persuaded (Douglas and Sutton, 2008).

Of particular importance here, some recent research has explored the impact of climate change conspiracy theories. Jolley and Douglas (2014b) asked people to read a paragraph about climate change. In one condition, the paragraph contained information supporting conspiracy theories (for example, that climate scientists are doctoring their data); in another condition, the paragraph refuted the conspiracy theories. Exposure to conspiracy theories reduced people's intentions to reduce their carbon footprint, relative to people who were given refuting information.

So, what can (or should) be done about climate change conspiracy theories? While scholars are waiting for more studies of climate change conspiracies specifically, they 
have suggested general strategies for undermining conspiracy theories to ensure public safety (for example, see Sunstein and Vermeule, 2009). These strategies include banning conspiracy theories altogether, imposing financial disincentives (such as taxes) on people who disseminate such theories, and engaging in "cognitive infiltration"joining conspiracy groups and counter-arguing against their conspiracy claims. However, these suggestions are arguably undemocratic, unreasonable, and impractical. They may also backfire, and the likelihood of "conversion" using scientific evidence is limited because climate change denial increasingly reflects ideological positions (Bain et al., 2012).

Instead of reactive approaches like these, it may instead be possible to take a proactive stance by addressing the underlying conditions that allow conspiracy theories to prosper. As in the field of medicine, approaches to climate change conspiracy theories could be therapeutic (akin to treating or curing an existing illness) or preventive (like seeking to avoid or reduce the occurrence of an illness). Several factors that are associated with conspiracy belief are alterable. Factors such as uncertainty (van Prooijen and Jostmann, 2013), feelings of powerlessness (Abalakina-Paap et al., 1999), political cynicism (Swami, 2012), magical thinking (Barron et al., 2014), and errors in logical and probabilistic reasoning (Brotherton and French, 2014) are all associated with belief in conspiracy theories. Addressing these factors may decrease reliance on conspiracy explanations. For example, business professors Jennifer Whitson and Adam Galinsky (2008) showed that a lack of control increases belief in conspiracy theories. Therefore, 
inducing instead a strong sense of control may reduce reliance on conspiracy theories. Future research will determine whether interventions are effective. They need not be tailored toward specific conspiracy theories, and they may have broader benefits such as improving openness and transparency in society, and critical and rational thinking in its citizens.

Exploring the impact of climate change conspiracy theories is timely and important. They cannot be dismissed as trivial or harmless. Governments and environmental professionals need to be aware that conspiracy theories may be detrimental to their efforts to encourage pro-environmental action. A future challenge for researchers will be to identify ways to responsibly deal with the consequences of climate change conspiracy theories.

\section{Author biographies}

Karen M. Douglas is a professor of social psychology at the University of Kent. She studies the social psychological factors associated with belief in conspiracy theories and the consequences of conspiracism. She is also interested generally in the social psychology of human communication. She is currently co-editor of the British Journal of Social Psychology. 
Robbie M. Sutton is a professor of social psychology at the University of Kent. He studies the social psychology of justice and inequality, including the psychological mechanisms that cause people to believe in conspiracy theories. He is lead author of the textbook Social Psychology (Palgrave Macmillan, 2013) and lead editor of Feedback: The Communication of Praise, Criticism and Advice (Peter Lang Publishing, 2012).

\section{Funding}

This research received no specific grant from any funding agency in the public, commercial, or not-for-profit sectors.

\section{References}

Abalakina-Paap M, Stephan WG, Craig T et al. (1999) Beliefs in conspiracies. Political Psychology 20(3): 637-647. Available at: http://onlinelibrary.wiley.com/doi/10.1111/0162-895X.00160/abstract.

Achenbach J (2006) The tempest. The Washington Post, May 28. Available at: http://www.washingtonpost.com/wpdyn/content/article/2006/05/23/AR2006052301305_pf.html

Bain PG, Hornsey MJ, Bongiorno R et al. (2012) Promoting pro-environmental action in climate change deniers. Nature Climate Change 2: 600-603. Available at: http://www.nature.com/nclimate/journal/v2/n8/full/nclimate1532.html.

Barron D, Morgan K, Towell T et al. (2014) Associations between schizotypy and belief in conspiracist ideation. Personality and Individual Differences 70: 156-159. 
Available at:

http://www.sciencedirect.com/science/article/pii/S0191886914003821.

Bandura A (2007) Impeding ecological sustainability through selective moral disengagement. International Journal of Innovation and Sustainable Development 2(1): 8-35. Available at: http://www.moraldisengagement.com/papers/MDEcology.pdf.

Brotherton R and French CC (2014) Belief in conspiracy theories and susceptibility to the conjunction fallacy. Applied Cognitive Psychology 28(2): 238-248. Available at: http://onlinelibrary.wiley.com/doi/10.1002/acp.2995/abstract..

Brulle RJ (2013) Institutionalizing delay: foundation funding and the creation of U.S. climate change counter-movement organizations. Climatic Change 122: 681694. Available at: http://link.springer.com/article/10.1007\%2Fs10584-013-10187\#page-1.

Chaiken S and Maheswaran D (1994) Heuristic processing can bias systematic processing: Effects of source credibility, argument ambiguity, and task importance on attitude judgment. Journal of Personality and Social Psychology 66(3): 460-473. Available at: http://psycnet.apa.org/psycinfo/1994-25314-001.

Coady D (ed.) (2006) Conspiracy Theories: The Philosophical Debate. Hampshire: Ashgate. Available at: http://www.ashgate.com/isbn/9780754652502.

Cohen GL (2003) Party over policy: The dominating impact of group influence on political beliefs. Journal of Personality and Social Psychology 85(5): 808-822. Available at: http://psycnet.apa.org/psycinfo/2003-09138-003. 
Douglas KM and Sutton RM (2008) The hidden impact of conspiracy theories:

Perceived and actual influence of theories surrounding the death of Princess

Diana. Journal of Social Psychology 148(2): 210-221. Available at:

http://www.ncbi.nlm.nih.gov/pubmed/18512419.

Dunlap RE and Jacques PJ (2013) Climate change denial books and conservative think tanks: exploring the connection. American Behavioral Scientist 57: 699-731.

Available at: http://abs.sagepub.com/content/57/6/699.

Feygina I, Jost JT and Goldsmith RE (2010) System justification, the denial of global warming, and the possibility of "system-sanctioned change." Personality and Social Psychology Bulletin 36(3): 326-338. Available at:

http://psp.sagepub.com/content/36/3/326.

Fischer D (2013) “Dark money” funds climate change denial effort. Scientific

American, December 23. Available at:

http://www.scientificamerican.com/article/dark-money-funds-climate-changedenial-effort/.

Gibson C (2012) Koch brothers exposed: Fueling climate denial and privatizing democracy, June 20. Available at: http://greenpeaceblogs.org/2012/04/02/kochbrothers-exposed-fueling-climate-denial-and-privatizing-democracy/.

Hovland CI and Weiss W (1951) The influence of source credibility on communication effectiveness. Public Opinion Quarterly 15(4): 635-650. Available at: http://poq.oxfordjournals.org/content/15/4/635.abstract. 
Howard BC (2014) Data deleted From UN climate report highlight controversies.

National Geographic, July 3. Available at:

http://news.nationalgeographic.com/news/2014/07/140703-ipcc-climate-reportdeleted-data-global-warming-science/.

Jolley D and Douglas KM (2014a) The effects of anti-vaccine conspiracy theories on vaccination intentions. PLoS ONE 9(2): e89177. Available at:

http://www.plosone.org/article/info\%3Adoi\%2F10.1371\%2Fjournal.pone.00891 $\underline{77}$.

Jolley D and Douglas KM (2014b) The social consequences of conspiracism: Exposure to conspiracy theories decreases intentions to engage in politics and to reduce one's carbon footprint. British Journal of Psychology 105(1): 35-56. Available at: http://onlinelibrary.wiley.com/doi/10.1111/bjop.12018/abstract.

Kahan DM, Peters E, Wittlin M et al. (2012) The polarizing impact of science literacy and numeracy on perceived climate change risks. Nature Climate Change, 2: 732-735. Available at: http://www.nature.com/nclimate/journal/v2/n10/full/nclimate1547.html.

Kunda Z (1990) The case for motivated reasoning. Psychological Bulletin 108(3): 480498. Available at: http://psycnet.apa.org/psycinfo/1991-06436-001.

Leman PJ and Cinnirella M (2007) A major event has a major cause: Evidence for the role of heuristics in reasoning about conspiracy theories. Social Psychological Review 9(2): 18-28. Available at: http://pure.rhul.ac.uk/portal/en/publications/amajor-event-has-a-major-cause-evidence-for-the-role-of-heuristics-in-reasoning- 
about-conspiracy-theories\%282ad8342b-f5ca-4791-b988ae70fbfdb4b3\%29.html.

Lewandowsky S, Gignac GE and Oberauer K (2013) The role of conspiracist ideation and worldviews in predicting rejection of science. PLoS ONE 8(10): e75637. Available at:

http://www.plosone.org/article/info\%3Adoi\%2F10.1371\%2Fjournal.pone.00756 $\underline{37 .}$

Leiserowitz A (2006) Climate change risk perception and policy preferences: The role of affect, imagery, and values. Climate Change 77: 45-72. Available at: http://link.springer.com/article/10.1007\%2Fs10584-006-9059-9.

Markowitz EM and Shariff AF (2012) Climate change and moral judgement. Nature Climate Change 2: 243-247. Available at: http://www.nature.com/nclimate/journal/v2/n4/abs/nclimate1378.html.

McCauley C and Jacques S (1979) The popularity of conspiracy theories of presidential assassination: A Bayesian analysis. Journal of Personality and Social Psychology 37(5): 637-644. Available at: http://psycnet.apa.org/psycinfo/1980$\underline{28000-001 .}$

Monbiot G (2009) Monbiot's royal flush: Top 10 climate change deniers. The Guardian, March 9. Available at: http://www.theguardian.com/environment/georgemonbiot/2009/mar/06/climatechange-deniers-top-10. 
NASA (2014) Global climate change: Vital signs of the planet. Available at http://climate.nasa.gov/.

Oreskes N and Conway EM (2010) Merchants of Doubt. New York: Bloomsbury.

Sedikides C, Gaertner L and Toguchi Y (2003) Pancultural self-enhancement. Journal of Personality and Social Psychology 84(1): 60-79. Available at: http://www.southampton.ac.uk/ crsi/pancultural2003.pdf.

Sunstein CR and Vermeule A (2009) Conspiracy theories: Causes and cures. Journal of Political Philosophy 17(2): 202-227. Available at: http://onlinelibrary.wiley.com/doi/10.1111/j.1467-9760.2008.00325.x/abstract.

Swami V (2012) Social psychological origins of conspiracy theories: The case of the Jewish conspiracy theory in Malaysia. Frontiers in Psychology 3: 280. Available at: http://www.ncbi.nlm.nih.gov/pmc/articles/PMC3412387/.

Taylor SE and Brown JD (1988) Illusion and well-being: A social psychological perspective on mental health. Psychological Bulletin 103(2): 193-210. Available at http://psycnet.apa.org/index.cfm?fa=search.displayRecord\&uid=1988-16903$\underline{001}$.

Tajfel H and Turner J (1979) An integrative theory of intergroup conflict. In: Worchel S and Austin WG (eds.) Psychology of Intergroup Relations. Michigan: NelsonHall Publishers, pp. 33-47. Available at: http://dtserv3.compsy.unijena.de/_C12579E500316406.nsf/0/916B517AB58093DDC12579E6002805C4 /\$FILE/Tajfel\%20\&\%20Turner\%201979.pdf. 
van Prooijen J-W and Jostmann NB (2013) Belief in conspiracy theories: The influence of uncertainty and perceived morality. European Journal of Social Psychology 43(1): 109-115. Available at: http://onlinelibrary.wiley.com/doi/10.1002/ejsp.1922/abstract.

Whitson JA and Galinsky AD (2008) Lacking control increases illusory pattern perception. Science 322(5898): 115-117. Available at: http://www.sciencemag.org/content/322/5898/115.

Weinstein ND (1980) Unrealistic optimism about future life events. Journal of Personality and Social Psychology 39(5): 806-820. Available at: http://psycnet.apa.org/journals/psp/39/5/806/.

Wohl MJA, Branscombe NR and Reysen S (2010) Perceiving your group's future to be in jeopardy: Extinction threat induces collective angst and the desire to strengthen the ingroup. Personality and Social Psychology Bulletin 36(7): 898910. Available at: http://psp.sagepub.com/content/36/7/898. short. 